\title{
Holstein-Friesian Strain and Feed Effects on Milk Production, Body Weight, and Body Condition Score Profiles in Grazing Dairy Cows
}

\author{
J. R. Roche, ${ }^{\star 1,2}$ D. P. Berry,† and E. S. Kolver \\ *Dexcel, Hamilton, New Zealand \\ †Teagasc Moorepark, Fermoy, Co. Cork, Ireland
}

\begin{abstract}
Data from 113 lactations across 76 cows between the years 2002 to 2004 were used to determine the effect of strain of Holstein-Friesian (HF) dairy cow and concentrate supplementation on milk production, body weight (BW), and body condition score (BCS; 1 to 5 scale) lactation profiles. New Zealand (NZ) and North American (NA) HF cows were randomly allocated to 1 of 3 levels of concentrate supplementation $[0,3$, or 6 $\mathrm{kg}$ of dry matter $(\mathrm{DM}) /$ cow per d] on a basal pasture diet. The Wilmink exponential model was fitted within lactation $\left(\mathrm{Y}_{\mathrm{DIM}}=\mathrm{a}+\mathrm{b} \times \mathrm{e}^{(-0.05 \times \mathrm{DIM})}+\mathrm{c} \times \mathrm{DIM}\right)$. The median variation explained by the function for milk yield was $86 \%$, between 62 and $69 \%$ for milk composition, and 80 and $70 \%$ for BW and BCS, respectively. North American cows and cows supplemented with concentrates had greater peak and 270-d milk yield. Concentrate supplementation tended to accelerate the rate of incline to peak milk yield, but persistency of lactation was not affected by either strain of HF or concentrate supplementation. No significant strain by diet interaction was found for parameters reported. New Zealand cows reached nadir BCS $14 \mathrm{~d}$ earlier and lost less BW (22 kg) postcalving than NA cows. Concentrate supplementation reduced the postpartum interval to nadir BW and BCS, and incrementally increased nadir BCS. New Zealand cows gained significantly more BCS (i.e., $0.9 \times 10^{-3}$ units/d more) postnadir than NA cows, and the rate of BCS replenishment increased linearly with concentrate supplementation from $0.5 \times 10^{-3}$ at $0 \mathrm{~kg}$ of $\mathrm{DM} / \mathrm{d}$ to $0.8 \times 10^{-3}$ and $1.6 \times 10^{-3}$ units $/ \mathrm{d}$ at 3 and $6 \mathrm{~kg}$ of DM/d concentrates, respectively. Although there was no significant strain by diet interaction for parameters reported, there was a tendency for a strain by diet interaction in 270-d BCS, suggesting that the effect of concentrate supplementation on BCS gain was, at least partly, strain dependent.
\end{abstract}

\footnotetext{
Received October 10, 2005.

Accepted February 21, 2006.

${ }^{1}$ Corresponding author: john.roche@utas.edu.au

${ }^{2}$ Present address: University of Tasmania, PO Box 3523, Burnie, Tasmania 7320, Australia.
}

Key words: Holstein-Friesian strain, pasture, concentrate supplementation, body condition score

\section{INTRODUCTION}

Understanding the relationship between strain of Holstein-Friesian (HF) cow and environment is becoming increasingly important because cows are now managed in a diverse range of environments worldwide (Veerkamp et al., 1994; Gordon et al., 1995; Horan et al., 2005a). Recent studies have shown strain by environment interactions (for review see Dillon et al., 2006), indicating that the most appropriate strain of cow will differ depending on the system of dairying under which she is managed.

Previously, breeding objectives focused mainly on milk production traits (Miglior, 2005). However, interactions between strain and feeding system have been observed for milk production (Veerkamp et al., 1994; Fulkerson et al., 2001; Kolver et al., 2002; Kennedy et al., 2003), feed efficiency (Wang et al., 1992), BW and BCS (Berry et al., 2003), and fertility (Kolver et al., 2002). The realization that these other factors can affect farm profitability has led to a change of direction toward more balanced, profit-focused breeding objectives globally (Miglior, 2005).

An understanding of how milk production, BW, and BCS change with time, as well as among strains of cow and feeding systems would assist in identifying the most suitable cow for different dairying systems. Buckley et al. (2003) reported a decline in fertility with increasing milk yield in the first $100 \mathrm{~d}$ relative to lactation yield (i.e., reduced persistency). Additionally, successfully manipulating body reserves is generally acknowledged as an important management factor, influencing animal health, milk production, and reproduction in the dairy cow (Stockdale, 2001; Buckley et al., 2003). Genetic selection for increased milk energy secretion in early lactation has produced a cow that will readily mobilize more body reserves, even to the detriment of her own health and fertility (Collard et al., 2000; Buckley et al., 2003). Therefore, the shape of the milk production curve and the pattern of change of BW and BCS throughout lactation have become of increasing interest 
as potential identifiers of appropriate cows for different systems.

Mathematical functions such as those previously used to describe a series of milk test-day records (Wood, 1976; Cobby and Le Du, 1978; Wilmink, 1987), have the advantage of minimizing random variation while simultaneously summarizing the lactation profile into biologically interpretable parameters. Several researchers (Tekerli et al., 2000; Horan et al., 2005a) have applied these equations to test-day observations to describe the shape of lactation profiles for milk, fat, and protein yield. Horan et al. (2005a) used the Wilmink function (Wilmink, 1987) to describe the lactation characteristics for milk, fat, and protein yield of dairy cows across 3 genotypes and 3 feeding systems. Previously reported BCS profiles (Mao et al., 2004) suggest a close resemblance to a horizontally inverted milk lactation curve. Hence, the applicability of a milk lactation function to BCS and BW requires further evaluation.

There are few studies that have applied such functions to comparisons of genetic strains and none that have applied them to grazing cows fed a constant level of supplementary feeds throughout lactation. Most studies reported to date have investigated the effect of HF strain in different farming systems, in which cows received varying amounts of supplementary feeds depending on the extent of the feed deficit experienced (Kennedy et al., 2003; Horan et al., 2005a). It is therefore not possible to separate the effect of concentrate supplementation on milk production profiles or BW and BCS change under grazing systems from the timing of supplementation, and any interaction between diet and HF strain. The objective of this study was to analyze lactation curves for milk production, BW, and BCS of 2 strains of HF cows, one originating in North America (NA) and the other in New Zealand (NZ), receiving 1 of 3 levels of concentrate $(0,3$, and $6 \mathrm{~kg}$ of $\mathrm{DM} / \mathrm{d})$ supplementation on a basal pasture diet, and to isolate the effect of strain and level of supplementation, and their interactions on the shape of the lactation curve.

\section{MATERIALS AND METHODS}

This experiment was conducted at Lye Farm, Dexcel, Hamilton, New Zealand $\left(37^{\circ} 46^{\prime} \mathrm{S} 175^{\circ} 18^{\prime} \mathrm{E}\right)$ from July 2002 to June 2004, and all procedures were approved by the Ruakura Animal Ethics Committee, Hamilton, New Zealand.

\section{Experimental Design}

In July 2002, 54 primiparous $(\mathrm{n}=16)$ and multiparous $(\mathrm{n}=38) \mathrm{HF}$ cows of 2 genetic strains $(\mathrm{NA}, \mathrm{n}=27$; $\mathrm{NZ}, \mathrm{n}=27$ ) were randomly allocated to 1 of 3 supple- mentary feeding treatments in a $2 \times 3$ factorial arrangement. In July 2003, 59 primiparous $(\mathrm{n}=5)$ and multiparous ( $\mathrm{n}=54) \mathrm{HF}$ (32 from $2002-2003$ and 27 additional) cows (NA, $n=29 ; N Z, n=30$ ) were randomly allocated to the same 3 supplementary feeding treatments. In total, data from 113 lactations on 76 cows were collected over the $2 \mathrm{yr}$.

All cows grazed a generous allowance ( $>45 \mathrm{~kg}$ of DM/ cow per d measured to ground level) of fresh pasture and 4 of the 6 groups (2 from each strain) received either 3 or $6 \mathrm{~kg}$ of $\mathrm{DM} / \mathrm{d}$ of a pelleted concentrate. The remaining 2 groups received no concentrates. Treatments were NZ0 ( $\mathrm{n}=9$ and 10 in 2002-2003 and 20032004, respectively), NZ3 ( $\mathrm{n}=9$ and 10 in 2002-2003 and 2003-2004, respectively), NZ6 ( $\mathrm{n}=9$ and 10 in 2002-2003 and 2003-2004, respectively), NA0 ( $\mathrm{n}=8$ and 9 in 2002-2003 and 2003-2004, respectively), NA3 ( $\mathrm{n}=10$ and 10 in 2002-2003 and 2003-2004, respectively), or NA6 ( $\mathrm{n}=9$ and 10 in 2002-2003 and 20032004, respectively).

Cow allocation ensured that treatments were balanced for age ( $5.1 \pm 1.60$ and $5.4 \pm 1.68 \mathrm{yr}$ in $2002-2003$ and 2003-2004, respectively), calving date (July $28 \pm$ $19.9 \mathrm{~d}$ and July $27 \pm 26.0 \mathrm{~d}$ in 2002-2003 and 20032004, respectively), and breeding worth (a measure of genetic merit accounting for the economic value of the trait; Harris et al., 1996). At the beginning of yr 2, cows were rerandomized, ensuring again that treatment groups were balanced for the same criteria as yr 1 .

\section{Strains}

The 2 strains compared were either of predominantly NA or NZ ancestry. The NA strain had $>87.5 \%$ NA genetic ancestry. The multiparous NA HF cows were either imported as embryos or were direct descendents of the embryos imported. The embryos referred to were imported from the United States and the Netherlands in 1996 by Holland Genetics Ltd. for Livestock Improvement Corporation, New Zealand, as part of their sireproving scheme. As such, the NA genetics used in the present experiment represent NA genetics that have been used widely in grazing systems.

After birth, progeny of the embryo imports were sold to commercial farmers and were subsequently purchased by Dexcel Ltd. prior to their first parturition. The primiparous NA cows were bred in New Zealand using NA sires available in New Zealand. The mean EBV of the sires used were obtained from the Livestock Improvement Corporation (New Zealand) evaluations (May 2005). The mean EBV for the NA animals on study were $+1,270(\mathrm{SD}=246.4) \mathrm{kg}$ of milk, $+32(\mathrm{SD}=$ 7.7) $\mathrm{kg}$ of fat, $+39(\mathrm{SD}=6.4) \mathrm{kg}$ of protein, $+93(\mathrm{SD}=$ 12.4) $\mathrm{kg}$ of $\mathrm{BW}$, and $-40(\mathrm{SD}=117.1) \mathrm{d}$ of survival. 
The NZ genetics used in the present experiment were selected from Dexcel herds based on their breeding worth and the proportion of NZ ancestry $(<12.5 \% \mathrm{NA}$ genes). The EBV for the NZ animals on study were $+820(\mathrm{SD}=225.5) \mathrm{kg}$ of milk, $+28.5(\mathrm{SD}=6.95) \mathrm{kg}$ of fat, $+28.4(\mathrm{SD}=5.90) \mathrm{kg}$ of protein, $+51.9(\mathrm{SD}=15.8)$ $\mathrm{kg}$ of BW and +324.5 (SD = 79.92) d of survival. Each strain represented 6 to 9 sires, which were common across feeding treatments within strain.

\section{Pasture Management and Supplementary Feeding Treatments}

Cows were rotationally grazed as one herd for the duration of the experiment and only returned to the same area when a minimum of 2 leaves had appeared on the majority $(>75 \%)$ of perennial ryegrass tillers. Cows had access to a fresh allocation of pasture daily. Pasture allowance ( $>45 \mathrm{~kg}$ of $\mathrm{DM} /$ cow per d) was sufficient to ensure unrestricted DMI (up to approximately $25 \mathrm{~kg}$ of DM/d) of fresh pasture in the unsupplemented cows. Pasture was of high quality throughout both years $(\mathrm{CP}=22.2 \pm 2.73 \% \mathrm{DM} ; \mathrm{OM}$ digestibility $=84.2 \pm 3.87 \%$ $\mathrm{DM} ; \mathrm{NDF}=40.0 \pm 4.38 \% \mathrm{DM} ; \mathrm{ADF}=22.2 \pm 2.50 \% \mathrm{DM}$; lipid $=4.1 \pm 0.25 \% \mathrm{DM}$; nonstructural carbohydrates $(\mathbf{N S C})=11.3 \pm 2.50 \% \mathrm{DM} ; \mathrm{ME}=11.8 \pm 0.54 \mathrm{MJ} / \mathrm{kg}$ of DM). Quality was maintained throughout the season, despite the high grazing residuals, through strategic use of mowing.

A flat rate of either 3 or $6 \mathrm{~kg}$ of DM of concentrates (32\% crushed barley, $60 \%$ crushed corn, $2 \%$ broll, $6 \%$ molasses; $\mathrm{CP}=11.2 \pm 1.46 \% \mathrm{DM} ; \mathrm{NDF}=9.8 \pm 1.99 \%$ $\mathrm{DM}$; lipid $=2.7 \pm 1.22 \% \mathrm{DM} ; \mathrm{NSC}=71.9 \pm 2.16 \% \mathrm{DM})$ were fed individually to the appropriate treatments. Concentrate allocation was equally split in 2 feeds daily during milking. For $15 \mathrm{~d}$ precalving, all cows were offered $2 \mathrm{~kg}$ of DM concentrate/d. Following calving, the NZ3 and NA3 cows received $3 \mathrm{~kg}$ of DM concentrates/ $\mathrm{d}$, and the NZ6 and NA6 cows were gradually stepped up to $6 \mathrm{~kg}$ of DM concentrates/d over the following $6 \mathrm{~d}$ $(0.5 \mathrm{~kg}$ of DM concentrates/d).

\section{Measurements}

Individual milk yields were recorded daily (Westfalia Surge, Oelde, Germany). Milk fat, CP, and lactose concentrations of the milk were determined by Milkoscan (Foss Electric, Hillerød, Denmark) on individual p.m. and a.m. aliquot samples collected on $1 \mathrm{~d} / \mathrm{wk}$. After calving, BW and BCS were determined weekly following the a.m. milking. Body condition score was assessed pre- and postcalving on a 10-point scale, where 1 is emaciated and 10 is obese (Macdonald and Roche, 2004). These scores were then converted to the 5-point scale of Wildman et al. (1982) using the regression equation generated by Roche et al. $(2004 ; \mathrm{USA}=1.5+0.32$ $\mathrm{NZ}$; in which USA $=5$-point scale and NZ $=10$-point scale).

In total, 4,927, 4,916, 4,924, and 4,924 records of milk yield, and fat, protein, and lactose percentages, respectively, and 5,420 and 4,224 records of $\mathrm{BW}$ and $\mathrm{BCS}$, respectively, were included in the analysis.

\section{Lactation Profiles}

The Wilmink (1987) exponential model was fitted to weekly measurements of milk yield, weekly fat, protein, and lactose percentages, and BCS and BW:

$$
y_{t}=a+b e^{-0.05 t}+c t .
$$

In this model, $a, b$, and $c$ are estimated parameters relating to the height of the curve, the initial phase of either incline or decline, and the subsequent phase of decline or incline, respectively. A negative $b$ parameter is indicative of an incline phase following calving, whereas a $b>0$ is indicative of a declining phase. Similarly, the $c$ parameter indicates a declining phase (postpeak) if negative, and an inclining phase (postnadir) when $c>0$.

In this equation, $y_{t}$ represents the variable in question at day $t$ of lactation. These regression parameters were estimated for each cow-lactation separately using PROC NLIN (SAS Institute, 2005). Residuals of each prediction variable were then calculated as the difference between the actual value of the dependent variable and the predicted value of the dependent variable at each day in milk. The root mean square prediction error (RMSE) was calculated as the standard deviation of the calculated daily residuals. The median $R^{2}$ of each lactation was calculated for each of the production variables separately.

The first derivate of the Wilmink function with respect to time $(d Y / d t)$ for each cow-lactation was set equal to zero and solved for DIM to determine when the instantaneous rate of daily change was zero; DIM was rounded to the nearest whole integer. This coincided with the day of occurrence for the maximum (i.e., peak) or minimum (i.e., nadir) point in the curve depending on the variable under investigation. Peak and total (270-d corrected) milk yield, the turning point of the lactation curves for milk components, the 270-d average of milk composition, and the nadir and average of BCS and BW were extrapolated from the fitted curves, as was the interval from calving to their occurrence. Initial investigation of the data on BCS revealed that a large proportion of animals (i.e., $26 \%$ of records) had a minimum point of BCS at d 270 (i.e., they never 
Table 1. Effect of strain of Holstein-Friesian and level of concentrate supplementation on estimated milk yield and milk composition parameters $^{1}$

\begin{tabular}{|c|c|c|c|c|c|c|c|c|c|c|c|}
\hline & Parameter & \multicolumn{2}{|c|}{ Strain $^{2}$} & SEM & \multicolumn{3}{|c|}{ Concentrate $^{3}$} & SEM & \multicolumn{3}{|c|}{$P$-value } \\
\hline \multicolumn{12}{|l|}{ Yield } \\
\hline \multirow{2}{*}{ Milk } & $\mathrm{b}$ & -10.2 & -11.1 & 0.77 & -9.1 & -11.1 & -11.8 & 0.96 & 0.41 & 0.09 & 0.90 \\
\hline & $\mathrm{c} \times 10^{-2}$ & -5.4 & -5.3 & 0.30 & -5.3 & -5.3 & -5.4 & 0.37 & 0.91 & 0.97 & 0.61 \\
\hline \multicolumn{12}{|c|}{ Composition } \\
\hline Fat & $\mathrm{a}$ & 3.59 & 3.17 & 0.073 & 3.53 & 3.45 & 3.18 & 0.090 & $<0.001$ & $<0.05$ & 0.54 \\
\hline \multirow[t]{3}{*}{ Protein } & a & 3.08 & 2.94 & 0.031 & 2.87 & 3.03 & 3.12 & 0.039 & $<0.01$ & $<0.001$ & 0.23 \\
\hline & $\mathrm{b}$ & 1.00 & 1.11 & 0.077 & 1.33 & 0.97 & 0.86 & 0.096 & 0.31 & $<0.05$ & 0.19 \\
\hline & $\mathrm{c} \times 10^{-3}$ & 3.37 & 3.50 & 0.178 & 4.03 & 3.25 & 3.03 & 0.222 & 0.57 & $<0.01$ & 0.16 \\
\hline \multirow[t]{3}{*}{ Lactose } & $\mathrm{a}$ & 5.02 & 5.01 & 0.025 & 4.98 & 5.03 & 5.03 & 0.032 & 0.60 & 0.32 & 0.67 \\
\hline & $\mathrm{b}$ & -0.46 & -0.42 & 0.051 & -0.48 & -0.34 & -0.49 & 0.063 & 0.30 & 0.20 & 0.61 \\
\hline & $\mathrm{c} \times 10^{-3}$ & -1.38 & -1.01 & 0.134 & -1.38 & -1.07 & -1.14 & 0.166 & $<0.05$ & 0.48 & 0.51 \\
\hline
\end{tabular}

${ }^{1} \mathrm{a}, \mathrm{b}$ and $\mathrm{c}$ are estimated parameters relating to the height of the curve, the initial phase of either incline or decline, and the subsequent phase of decline or incline, respectively.

${ }^{2}$ Strains: NZ = Holstein-Friesian of New Zealand origin; NA = Holstein-Friesian of North American origin.

${ }^{3}$ Concentrate (Con) level: 0 , 3, or $6 \mathrm{~kg}$ of DM/d.

had an ascending phase). Hence, across all animals, the point of BCS nadir was assumed to be the DIM at the initiation of the linear (final) phase of the Wilmink function.

\section{Statistical Analysis}

A mixed model analysis using PROC MIXED (SAS Institute, 2005) was performed separately on the 3 parameters derived from the Wilmink function. The model used was:

$$
\mathrm{R}_{h i j k}=\mu+\mathrm{S}_{i}+\mathrm{C}_{j}+(\mathrm{S} * \mathrm{C})_{i j}+\mathrm{Y}_{k}+\mathrm{A}_{\mathrm{h}}+\mathrm{e}_{h i j k}
$$

where $\mathbf{R}_{h i j k}=$ the response for the animal $h$ of strain $i$ on feeding system $j$ in year $k ; \mathrm{S}_{i}=$ the effect of $i$ th strain of $\mathrm{HF}$ ( $i=\mathrm{NZ}$ or NA); $\mathrm{C}_{j}=$ concentrate feeding level $(j=$ $0,3,6 \mathrm{~kg}$ of DM/cow per d); $\mathrm{Y}_{k}=$ the effect of $k$ th year; $\mathrm{A}_{\mathrm{h}}=\operatorname{animal} h$; and $\mathrm{e}_{h i j k}=$ the residual error term. Animal was treated as a repeated effect in the model. The $F$-test was used to determine the significance of the effect of the explanatory variables on the dependent variables, and the Student's simple $t$-test was used to determine the significance of differences between strains of $\mathrm{HF}$ and in the comparison of concentrate feeding levels.

\section{RESULTS}

There was no difference in the amount of concentrate DM eaten daily between strains in either year. New Zealand cows ate either $2.9(2.9 \pm 0.39$ and $3.0 \pm 0.19$ in 2002-2003 and 2003-2004, respectively) or 5.7 (5.5 \pm 0.87 and $5.8 \pm 0.70$ in 2002-2003 and 2003-2004, respectively) $\mathrm{kg}$ of DM concentrates/d in their respective treatments, and NA cows ate either $2.9(2.9 \pm 0.35$ and $3.0 \pm 0.20$ in 2002-2003 and 2003-2004, respectively) or 5.7 (5.5 \pm 0.85 and $5.8 \pm 0.75$ in $2002-2003$ and 2003-2004, respectively) $\mathrm{kg}$ of DM concentrates/d.

All residuals were normally distributed and the function applied represented a good fit to the data. The median $\mathrm{R}^{2}$ for daily milk yield (0.86) was greater than that of fat (0.62), protein (0.69), and lactose percentage (0.69), which were not greatly different from each other. The median RMSE for milk yield, milk fat percentage, protein percentage, and lactose percentage were 1.59 $\mathrm{kg}, 0.35 \%, 0.16 \%$, and $0.10 \%$, respectively. The median $\mathrm{R}^{2}$ for BW and BCS were 0.80 and 0.70 , respectively, and the median RMSE were $13.5 \mathrm{~kg}$ and $0.113 \mathrm{BCS}$ units, respectively.

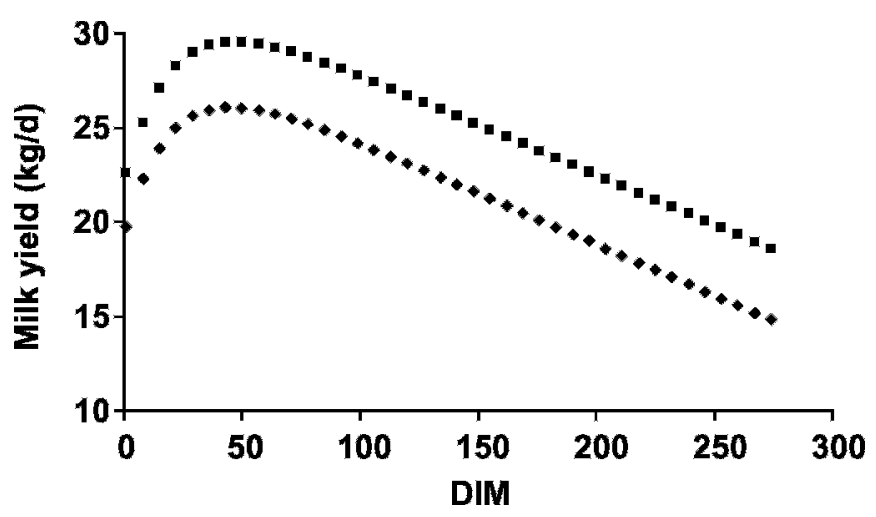

Figure 1. Effect of strain of Holstein-Friesian dairy cow on the lactation profile for milk yield. Strains were either of North American $(\square)$ or New Zealand $(\bullet)$ origin. 

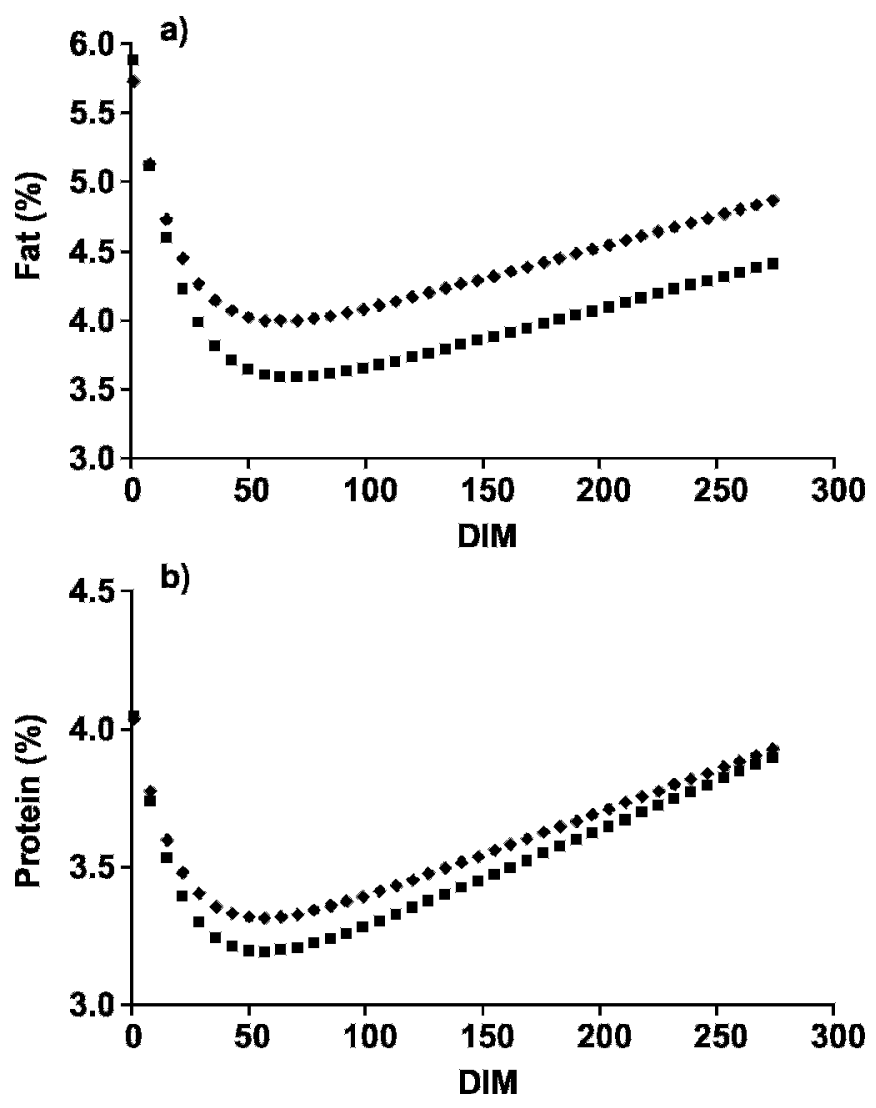

Figure 2. Effect of strain of Holstein-Friesian dairy cow on the lactation profile for milk fat and protein percentage. Strains were either of North American ( $\mathbf{\square})$ or New Zealand ( ) origin.

\section{Milk Production}

Of the variables investigated, year had a significant effect on only the $c$ parameter of the Wilmink function fitted to milk yield, and the DIM at peak lactose percentage.

Effect of Strain. The effect of strain on milk yield and milk composition parameters are reported in Table 1 , with the fitted curves displayed in Figures 1 and 2. The $a$ parameter (i.e., the height of the curve) was greater for milk yield $(P<0.01)$, and lower for fat and protein percentage in NA cows $(P<0.01)$, with no effect of strain on lactose percentage. The $b$ parameter for milk yield and lactose percentage was negative, indicating a postcalving (prepeak) incline phase, whereas fat and protein percentage had a positive $b$ parameter, corresponding to a postcalving (prenadir) decline phase. Strain did not affect the size of the $b$ parameter for milk yield, or the concentration of protein or lactose, but NA cows had a higher $(P<0.01) b$ parameter for fat percentage, indicative of a more rapid postcalving decline. The negative $c$ parameter for milk yield indicates a declining postpeak phase; this parameter was

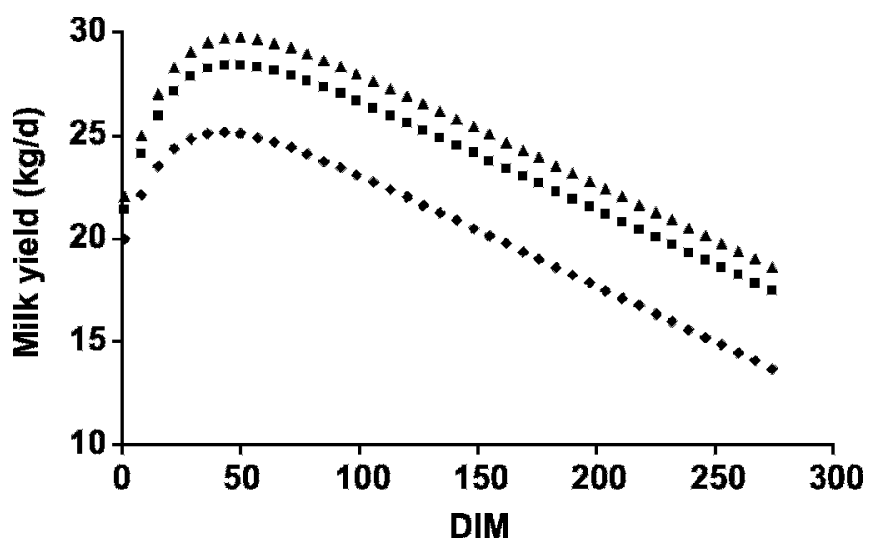

Figure 3. Effect of level of concentrate supplementation on the lactation profile for milk yield in cows receiving $0(\bullet), 3(\boldsymbol{\square})$, or $6(\boldsymbol{\Delta})$ $\mathrm{kg}$ of DM of a concentrate pellet daily throughout lactation.

not significantly affected by strain. Fat and protein percentage exhibited ascending postnadir phases and were not affected by strain. Lactose percentage had a negative $c$ parameter, indicative of a postpeak decline, and the $c$ parameter was more negative $(P<0.05)$ for NZ cows than for NA cows.

The ancillary milk production variables derived from the fitted curves are presented in Table 2. Cows of NA origin produced $930 \mathrm{~kg} / \mathrm{cow}$ more $(P<0.001)$ milk with lower $(P<0.01)$ concentrations of fat $(0.41$ percentage units) and protein ( 0.12 percentage units). This effect of NA strain was also evident at the profile turning points (peak milk yield and nadir fat and protein concentration). Nadir fat concentration was reached earlier in NZ cows $(P<0.05)$, but there was no effect of strain on DIM to peak milk yield or lactose percentage, or nadir protein concentration.

Effect of Concentrate. The effects of concentrate supplementation on milk yield and milk composition parameters are reported in Table 1, with the fitted curves displayed in Figures 3 and 4 . There was no strain by concentrate supplementation interaction in any of the milk production parameters. Supplementing cows with concentrates increased the height of the lactation profile for milk yield. The $a$ parameters for protein and fat concentration increased and decreased, respectively, with concentrate supplementation $(P<0.05)$, whereas lactose concentration was unaffected. The $b$ parameter for protein concentration decreased linearly $(P<0.05)$ and there was a trend for the $b$ parameter for milk yield to become more negative $(P<0.10)$ with increasing concentrate supplementation, indicating a more rapid accession to peak milk yield and a slower decline in protein percentage toward nadir with concentrate supplementation. Concentrate supplementation affected $(P<0.05)$ the $c$ parameters for protein percent- 
Table 2. Effect of strain of Holstein-Friesian and level of concentrate supplementation on 270-d total milk yield (kg) and average 270-d milk composition $(\%)$, milk yield $(\mathrm{kg} / \mathrm{d})$, and milk composition $(\%)$ at the turning point of the profile (peak/nadir), and DIM at the turning point of the respective curves

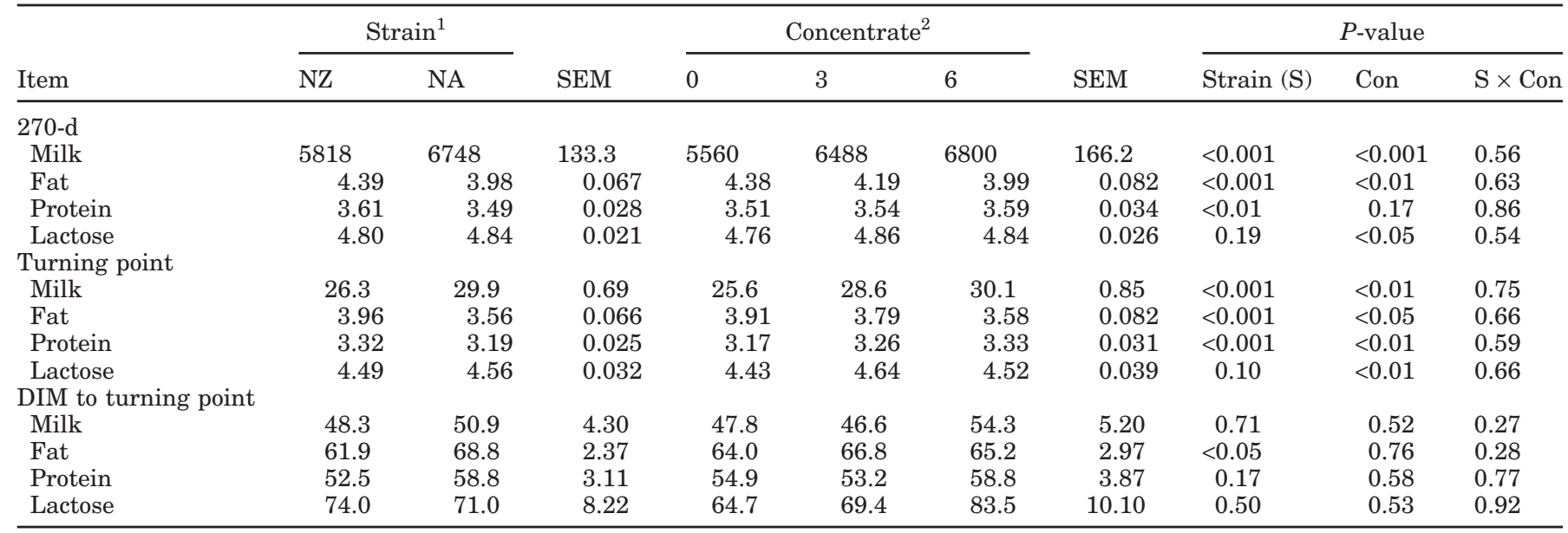

${ }^{1}$ Strains: NZ = Holstein-Friesian of New Zealand origin; NA = Holstein-Friesian of North American origin.

${ }^{2}$ Concentrate (Con) level: 0,3 , or $6 \mathrm{~kg}$ of $\mathrm{DM} / \mathrm{d}$.

age only, reducing the rate at which protein percentage increased postnadir, thereby compensating for the reduced rate of decline prenadir and resulting in a similar milk protein percentage across concentrate supplementation treatments by the end of lactation (d 270).

Concentrate supplementation increased 270-d milk yield, milk yield at peak, milk protein and lactose concentration at the turning point of the profile, average 270-d milk lactose concentration, but reduced average 270-d milk fat concentration and the milk fat concentration at the point of nadir. The time to peak milk yield averaged $49 \mathrm{~d}$, but was not affected by feeding treatment. Nadir fat and protein concentration and peak lactose concentration occurred at 65,55 , and 73 DIM, respectively, and were not significantly affected by concentrate feeding.

\section{$B W$ and BCS Parameters}

The effects of strain, concentrate supplementation, and strain by concentrate interaction for estimated BW and BCS parameters are presented in Table 3 and displayed in Figures 5 and 6. Year significantly affected all parameters of the Wilmink function when fitted to BW but only the $c$ parameter when fitted to BCS.

Effect of Strain. The $a$ parameter for BW was higher $(P<0.001)$ for NA cows, which lost BW at a greater $(P$ $<0.01)$ rate postcalving ( $b$ parameter). The difference in the $a$ parameter $(65.2 \mathrm{~kg})$ was close to that expected from the difference in their respective average EBV for BW $(41.1 \mathrm{~kg})$. The postnadir rate of gain ( $c$ parameter) was not significantly affected by strain of $\mathrm{HF}$ cow. The $a$ parameter for BCS was greater $(P<0.05)$ for NZ cows (2.73 BCS units) compared with the NA strain (2.63 BCS units). Strain did not significantly affect the rate of BCS loss postcalving, but NZ cows gained BCS more rapidly $(P<0.001)$ postnadir than NA cows.

The BW and BCS measures derived from the fitted curves are presented in Table 4. North American cows were heavier $(P<0.001)$ at calving, at nadir, and at the end of lactation (d 270), but lost $26 \%$ more $(P<$

Table 3. Effect of strain of Holstein-Friesian and level of concentrate supplementation on estimated BCS and BW parameters ${ }^{1}$

\begin{tabular}{|c|c|c|c|c|c|c|c|c|c|c|c|}
\hline Item & Parameter & \multicolumn{2}{|c|}{ Strain $^{2}$} & SEM & \multicolumn{3}{|c|}{ Concentrate $^{3}$} & SEM & \multicolumn{3}{|c|}{$P$-value } \\
\hline \multirow[t]{2}{*}{ BW } & a & 451.2 & 516.4 & 10.91 & 483.3 & 480.8 & 487.3 & 13.53 & $<0.001$ & 0.94 & 0.77 \\
\hline & $\mathrm{c}$ & 0.32 & 0.32 & 0.018 & 0.27 & 0.29 & 0.41 & 0.023 & 0.71 & $<0.001$ & 0.51 \\
\hline \multirow{2}{*}{ BCS } & a & 2.73 & 2.63 & 0.041 & 2.64 & 2.65 & 2.74 & 0.050 & 0.09 & 0.33 & 0.92 \\
\hline & b & 0.54 & 0.56 & 0.044 & 0.62 & 0.53 & 0.50 & 0.055 & 0.89 & 0.38 & 0.68 \\
\hline
\end{tabular}

\footnotetext{
${ }^{1} \mathrm{a}, \mathrm{b}$ and $\mathrm{c}$ are estimated parameters relating to the height of the curve, the initial phase of decline, and the subsequent incline phase, respectively.

${ }^{2}$ Strains: NZ = Holstein-Friesian of New Zealand origin; NA = Holstein-Friesian of North American origin.

${ }^{3}$ Concentrate (Con) level: 0 , 3, or $6 \mathrm{~kg}$ of DM/d.
} 

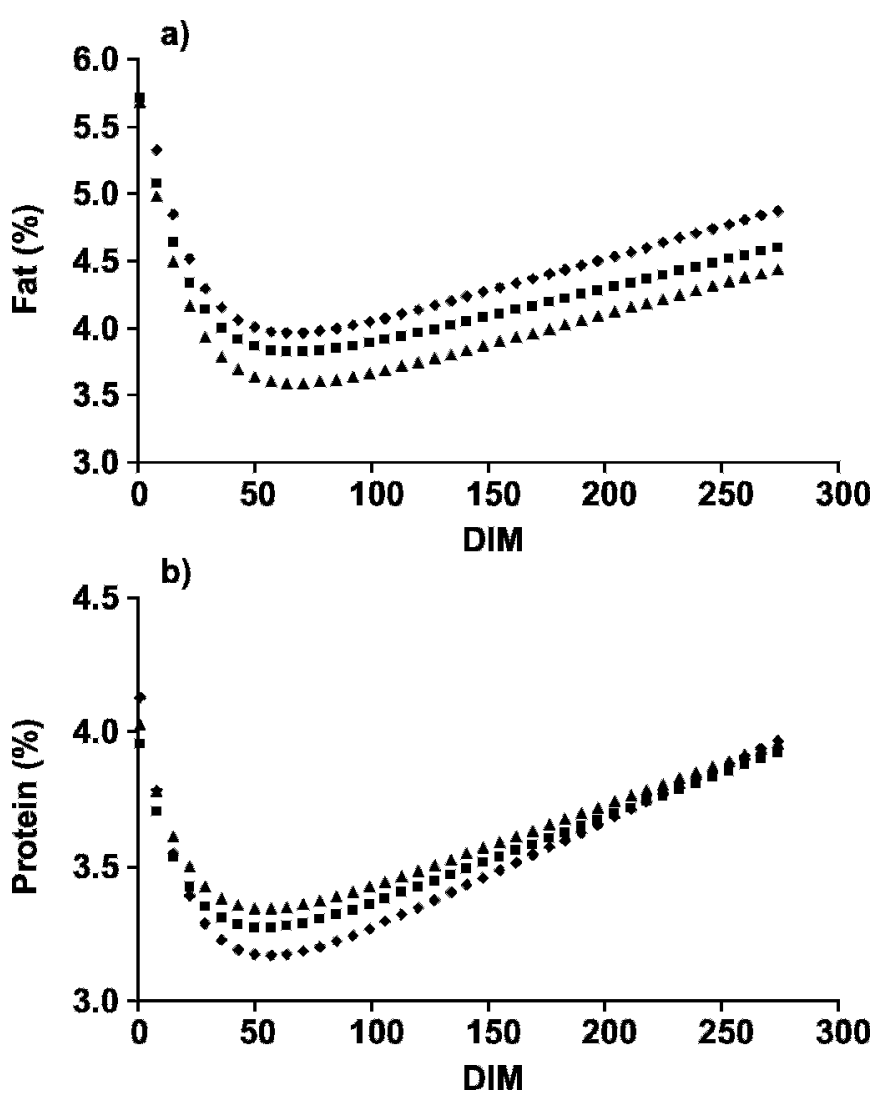

Figure 4. Effect of level of concentrate supplementation on the lactation profile for milk fat and protein percentage. Cows received $0(\downarrow), 3(\mathbf{\square})$, or $6(\boldsymbol{\Delta}) \mathrm{kg}$ of DM of a concentrate pellet daily throughout lactation.

0.001) BW between calving and nadir than NZ cows ( 84 vs. $62 \mathrm{~kg}$ of BW). This equated to 75 and $61 \%$ of $\mathrm{BW}^{0.75}$ for NA and NZ cows, respectively. Strains were managed to calve at a similar BCS, but NA cows had a lower $(P<0.001)$ BCS at nadir and dry off. North American cows lost BCS for $14 \mathrm{~d}$ longer $(P<0.01)$ than NZ cows, and gained less BCS postnadir $(P<0.001)$, resulting in a lower BCS at DIM 270 (0.32 units; $P<0.001)$.

Effect of Concentrate. Concentrate supplementation did not affect the $a$ parameter for either BW or $\mathrm{BCS}$, nor the postcalving rate of decline to nadir. However, the postnadir rate of gain ( $c$ parameter) in $\mathrm{BW}$ and BCS increased linearly with increasing concentrate level.

Cows receiving concentrates calved at the same $\mathrm{BW}$ and BCS, and although concentrate supplementation did not affect nadir BW, there was a linear increase in nadir BCS with increasing concentrate supplementation $(P<0.05)$. Concentrate supplementation reduced the DIM to nadir BW $(P<0.05)$ and BCS $(P<0.01)$, and increased BW $(P<0.05)$ and BCS at dry off $(P<$ 0.001). Condition lost postcalving tended to decrease with concentrate supplementation $(P<0.10)$, but BW loss was not affected. There was a tendency for a strain by concentrate level interaction in BCS at dry off $(P=0.15)$.

\section{DISCUSSION}

The objective of the present study was to quantify the difference, if any, in lactation profiles for milk production, BW and BCS across 2 contrasting genotypes of animals on 3 levels of concentrate supplementation. The present data set (113 lactations from 76 cows) may be considered small for this purpose. However, it has the unique advantage of comparing $\mathrm{HF}$ cows selected under very different breeding objectives (as predicted by EBV for production and nonproduction traits), and determining the true response of these cows to concentrate supplementation under grazing. Previous research (Jonsson et al., 1999; Kennedy et al., 2003; Horan et al., 2005a,b, 2006) examined cows from different strains under different feeding systems. However, the effect of strain in many of those studies was affected by genetic merit for milk production of the cows (Kennedy et al., 2003; Horan et al., 2005a,b, 2006), and the fact that level of concentrate supplementation was not constant throughout lactation, but depended on the amount of fresh pasture that was available for grazing. In the current study, cows were fed a generous allowance of pasture and a constant rate of concentrate throughout lactation, allowing the true response of different strains of dairy cows to concentrate supplementation to be measured for pasture diets, without the confounding effect of different farming systems. In addition, we are unaware of other studies that have used the reported exponential function to fit profiles to BCS.

\section{Milk Production}

The greater milk production and lower component concentration of milk from NA HF cows is consistent with their EBV and has been reported previously (Kennedy et al., 2003; Horan et al., 2005a). This result highlights the different breeding objectives under which the strains developed. The NA strain were imported from the United States and the Netherlands, where more heavy emphasis had been placed on breeding for milk yield (Fulkerson et al., 2001) compared with New Zealand (Harris and Kolver, 2001), mainly because of differences in the milk pricing structures in the respective countries.

A key difference between the results presented here and those presented by Horan et al. (2005a), who also reported lactation profiles for milk production across alternative genetic strains of $\mathrm{HF}$ on a basal pasturebased diet, is the lack of an effect of strain on the shape 
a)

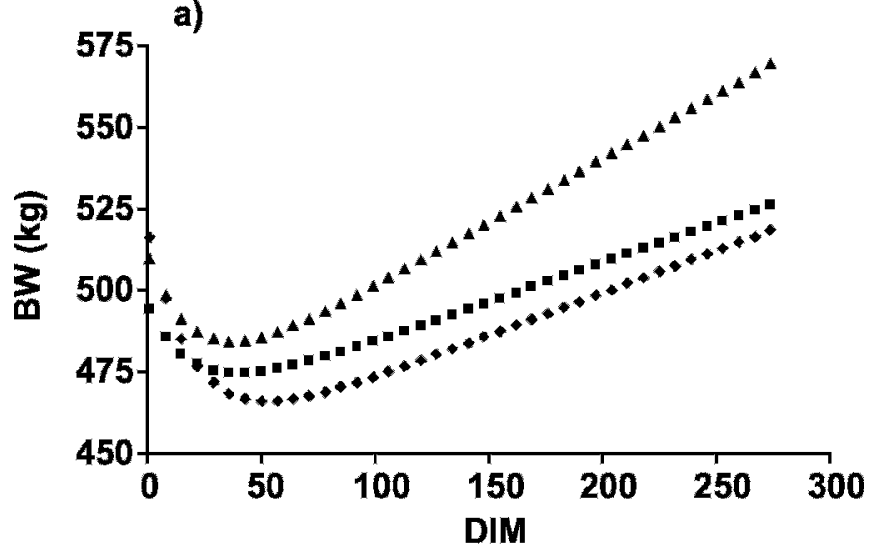

b)

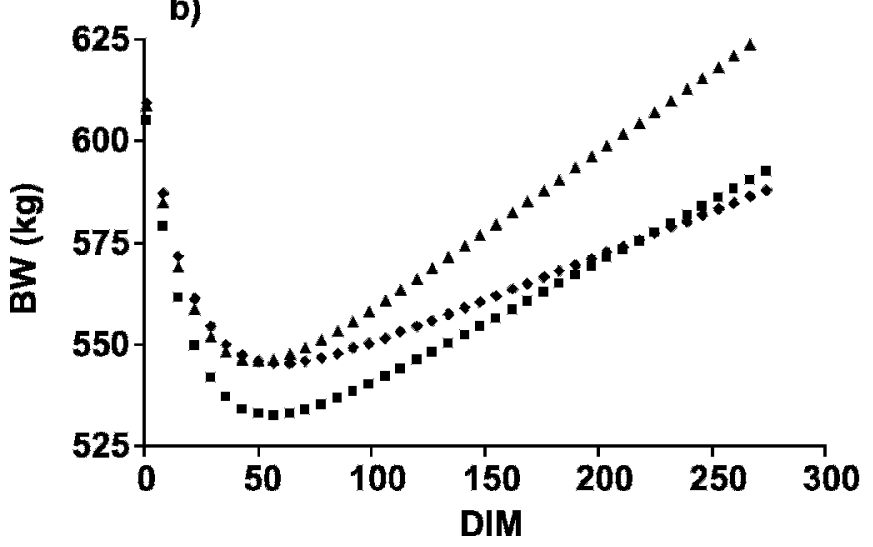

Figure 5. Effect of strain of Holstein-Friesian dairy cow and level of concentrate supplementation on the lactation profile for BW. Strains were either of (a) New Zealand or (b) North American origin

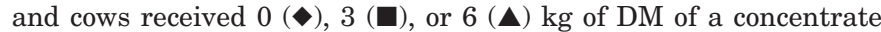
pellet daily throughout lactation.

of the lactation curve in the present study. Although the $a$ parameter (the height of the curve) was higher in NA cows, there was no effect of strain on either the prepeak incline phase ( $b$ parameter) or the postpeak persistency (c parameter) in the present study. Horan et al. (2005a) reported strain effects in both of these parameters with NA cows displaying an accelerated rise to peak milk but poorer persistency (i.e., a steeper curve). The reason for this difference is not clear, but may be a result of the farm-system nature of supplementation in their study, whereby supplements were fed in both early and late lactation when there was insufficient pasture, but not in mid lactation. In the study presented here cows received a flat rate of supplementation, removing the confounding effect of timing of feeding decisions on the shape of the lactation curve.

The observed increase in milk yield with increasing concentrate supplementation has been reported elsewhere (see review by Bargo et al., 2003; Kennedy et al., 2003; Horan et al., 2005a). Although each kilogram of
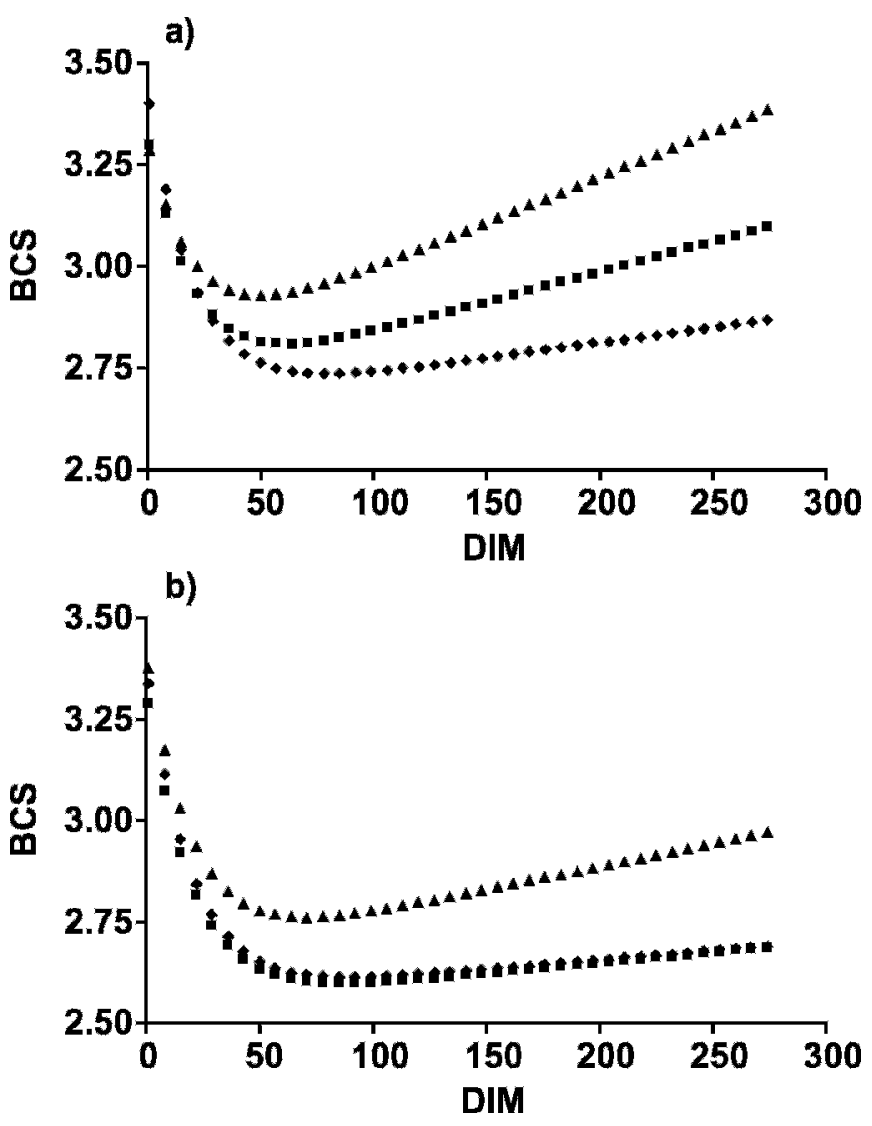

Figure 6. Effect of strain of Holstein-Friesian dairy cow and level of concentrate supplementation on the lactation profile for BCS. Strains were either of (a) New Zealand or (b) North American origin and cows received $0(\bullet), 3(\boldsymbol{\square})$, or $6(\boldsymbol{\Delta}) \mathrm{kg}$ of DM of a concentrate pellet daily throughout lactation.

concentrate contains sufficient $\mathrm{NE}_{\mathrm{L}}$ to produce approximately $1.6 \mathrm{~kg}$ of milk, milk yield increased by only 0.77 $\mathrm{kg} / \mathrm{kg}$ of DM concentrates across both strains. Furthermore, this response declined from $0.88 \mathrm{~kg}$ of milk at the low rate of supplementation to $0.66 \mathrm{~kg}$ of milk at $6 \mathrm{~kg}$ of DM concentrates/d. This decline in marginal milk response to increasing concentrate supplementation is well documented (Kellaway and Porta, 1993). Poorer responses to concentrates than would be theoretically expected result from a decline in pasture DMI when supplementary feeds are offered (McGilloway and Mayne, 1996; Dixon and Stockdale, 1999). Time spent grazing declines with supplementation by approximately $12 \mathrm{~min} / \mathrm{kg}$ of concentrate DM (Bargo et al., 2003), leading to substitution of the supplemented feed for grazed pasture. Substitution rate tends to increase with increasing pasture allowance (Stakelum, 1986; Penno, 2002) resulting in the declining marginal milk response to additional concentrates recorded here.

In the current study, cows were well fed on pasture and this would likely result in very high substitution 
Table 4. Effect of strain of Holstein-Friesian and level of concentrate supplementation on BW and BCS at calving, nadir, and end of lactation (dry off), in addition to changes between these points in time, and DIM to BCS/BW nadir

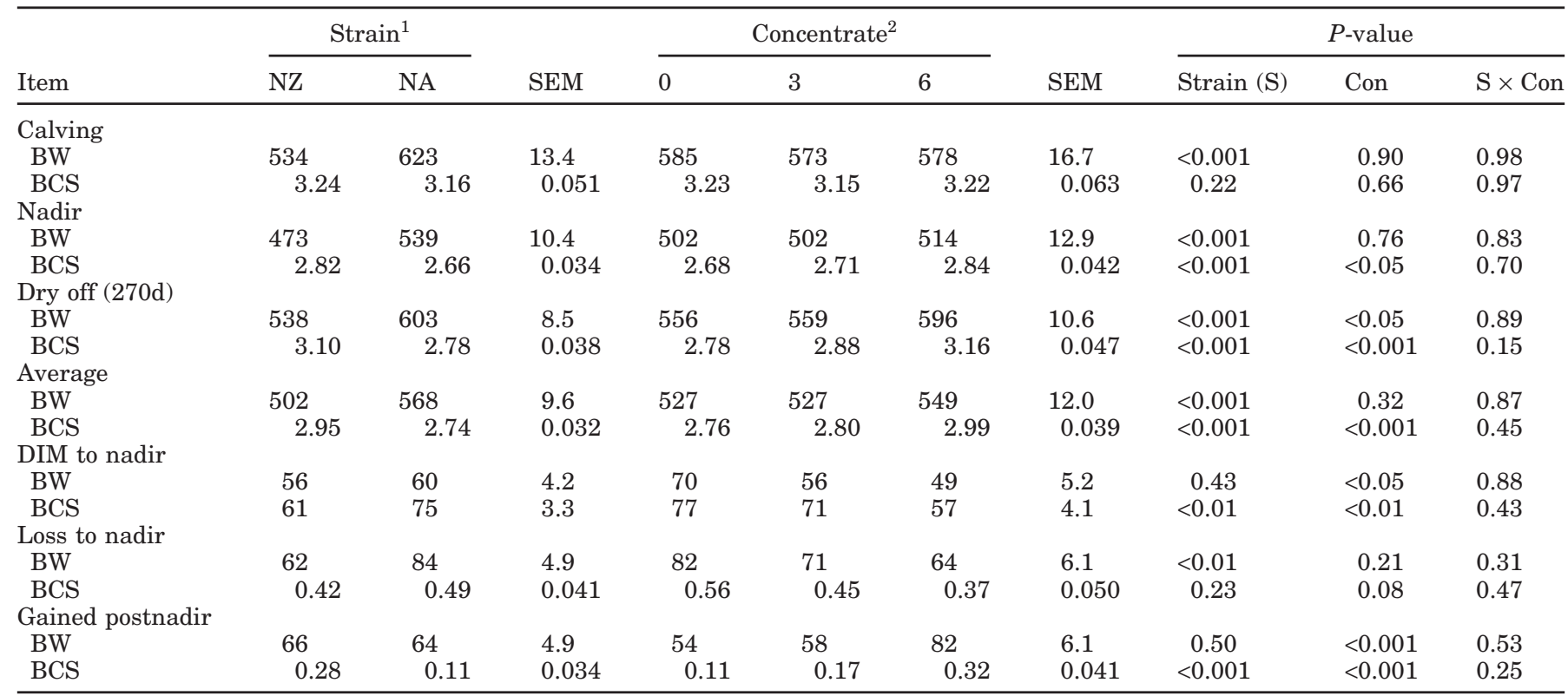

${ }^{1}$ Strains: NZ = Holstein-Friesian of New Zealand origin; NA = Holstein-Friesian of North American origin.

${ }^{2}$ Concentrate (Con) level: 0,3 , or $6 \mathrm{~kg}$ of $\mathrm{DM} / \mathrm{d}$.

rates and low marginal milk responses to additional concentrates. The above responses could therefore be regarded as the minimum responses expected from concentrate supplementation to grazing dairy cows. These responses are much higher than previously reported $(0.3$ to $0.5 \mathrm{~kg}$ of milk/ $\mathrm{kg}$ of DM concentrate; Journet and Demarquilly, 1979; Dillon et al., 1997), but are consistent with more recent work in high-yielding cows $(>1.0$ $\mathrm{kg}$ of milk/kg of DM concentrate; Bargo et al., 2002; Kennedy et al., 2003). Kennedy et al. (2003) concluded that progress in genetic selection for increased milk yield also increased the marginal milk response to concentrate supplementation, probably because of the greater negative energy balance in high genetic merit cows. The lack of an interaction between strain and concentrate supplementation in the current work probably reflects the similar genetic merit for milk fat and protein production in the different strains.

Supplementing cows that were fed generous quantities of fresh pasture with concentrates elevated the height of the milk production curve but otherwise did not affect the shape of the curve. There was a trend ( $P$ $<0.10$ ) for a greater rate of gain in milk yield before peak in cows receiving concentrates, which supports the earlier work of Horan et al. (2005a), but, unlike their results, there was no effect of concentrates on postpeak persistency. This inconsistency may be a result of a previously mentioned confounding effect of farm system and timing of concentrate supplementation in the study re- ported by Horan et al. (2005a). Response to concentrates is higher in cows superior in genetic merit for milk production (Kennedy et al., 2002), and the marginal response does not decline with increasing concentrate supplementation (Bargo et al., 2003), provided there is no negative effect on rumen health. The cows in the current study were fed generously on pasture throughout the season, and supplemented with concentrates irrespective of energy requirements and balance. The study reported by Horan et al. (2005a) was a farm-systems experiment, supplementing cows with supplements only when pasture supply was insufficient to meet DMI requirements. As previously outlined, the milk production response to concentrate supplementation would be expected to be greater in cows in greater negative energy balance. Therefore, the measured marginal milk response to concentrates would be expected to be constant where supplementation strategy was constant, as in the current study, but one would expect a greater response to concentrates during periods of energy deficit, as in the feeding strategy used by Horan et al. (2005a). Such a feeding strategy would be expected to alter the shape of the lactation curve.

The negative effect of concentrates on milk fat concentration is well documented (Spörndly, 1991; Bargo et al., 2002), although inconsistent (Dillon et al., 1997; Robaina et al., 1998). Nevertheless, Bargo et al. (2003) reported that in general there was a negative relationship among milk fat concentration, concentrate DMI, and the reduc- 
tion in pasture DMI that comes with concentrate feeding. This effect was consistent throughout lactation in the present analysis, reducing the $a$ parameter linearly with increasing concentrate intake. The linear increase in average milk protein concentration is also consistent with the literature (Spörndly, 1991), although the response may be inversely related to the digestibility of the forage being fed (Dillon et al., 1997). In general, there is a positive relationship between concentrate DMI and milk protein, with a 0.01-percentage unit increase in milk protein with each $1 \mathrm{~kg}$ of DM increase in concentrate DMI (Bargo et al., 2003). The 0.03 and 0.08 percentage unit increases in milk protein concentration from cows consuming either 3 or $6 \mathrm{~kg}$ of DM concentrates in this study are consistent with this relationship.

\section{$B W$ and $B C S$}

The greater postcalving BW loss and the lower nadir BCS in NA cows is consistent with the literature (Horan et al., 2005b) and indicates that much of the additional milk produced by NA cows in grazing systems is derived from body tissue. It also points to a greater negative energy balance in NA cows in early lactation compared with NZ cows. Horan et al. (2006) reported greater DMI in NA HF cows when compared with NZ HF cows of lower genetic merit for milk production. In comparison, Kolver et al. (2002) reported no such effect of strain in animals of similar genetic merit for milk fat and protein production. The increase in body tissue-derived milk production in NA HF in early lactation in the current study therefore suggests a genetic selection influence on homeorhetic mechanisms.

Without metabolic or physiological measures it is not possible to identify the physiological and metabolic changes that have been indirectly selected for. However, changes in the production of, and tissue sensitivity to, key hormones during the genetic selection process are prime candidates for speculation. Growth hormone $(\mathbf{G H})$ is one potential homeorhetic control mechanism that is known to have changed under selection for increased milk yield (Hart et al., 1978). Growth hormone is one of several periparturient hormones that facilitates increased fat mobilization (Lucy et al., 2001) and hepatic gluconeogenesis (Etherton and Bauman, 1998), paving the way for increased milk production. The reported effects of strain on BW and BCS are possibly a result of both a direct effect of GH on the associated metabolic pathways, and an antagonistic effect of GH on the responsiveness of peripheral tissues to insulin (increased insulin resistance; Vernon, 1989; Etherton and Bauman, 1998). Strain differences in hepatic GH receptor (GHR) in early lactation and the duration of depressed postpartum GHR concentration (M. C. Lucy, Univ. Missouri,
Columbia; personal communication) supports this genetic selection for changes in homeorhetic mechanisms.

Other potential candidate hormones whose concentrations have been altered in high-producing dairy cows are prolactin and insulin (Hart et al., 1978). Prolactin is a pituitary hormone that plays multiple roles in the homeorhetic adaptation to lactation. Blocking prolactin release reduced milk production by 40 to $50 \%$ and increased body tissue gain (Bauman and Currie, 1980), supporting the premise that increases in prolactin in dairy cows producing greater volumes of milk may be a reason for the genetic strain differences in milk production and BW and BCS change reported here. Similarly, insulin is a potent regulator of lipogenesis (Vernon, 1992) as well as an antagonist to the lipolytic actions of $\mathrm{GH}$, through its positive effect on hepatic and adipose tissue GHR concentration (Rhoads et al., 2004). Depressed insulin production (Hart et al., 1978) and greater resistance to insulin (Xing et al., 1993) in higher yielding cows is consistent with the greater BW loss and lower nadir BCS in the data reported here. The diminished rate of BCS accession ( $c$ parameter) postnadir points to a failure of NA cows to attain a positive energy balance commensurate with their NZ counterparts, and supports the hypothesis that these strains differ in either their concentration of particular hormones, their responsiveness to these hormones at a tissue level, or both. Further research is required to determine strain differences in these key metabolic and physiological parameters.

Supplementary feeding did not affect the rate of loss of BW or BCS postcalving, but shortened the period of loss and increased the rate of BW and BCS accretion postnadir. The lack of an effect of feeding on the rate of BW and BCS loss is consistent with the results reported by Roche (2006), that a feed restriction in early lactation reduced milk production, but did not affect BCS or BW loss. Roche (2006) hypothesized this to be a result of the downregulation of GHR-1A at calving (Kobayashi et al., 1999), the resultant natural uncoupling of the GH-IGFI axis (Rhoads et al., 2005), and a failure of nutrition to further influence this until hepatic GHR levels recover. The physiological actions of GH are initiated when GH binds to GHR on target cells (Nelson and Cox, 2005). The greatest density of GHR is found in liver and adipose tissue (Lucy et al., 2001). Recovery of the parturitionrelated attenuation of hepatic GHR density in the dairy cow occurs by around 3 wk postcalving in TMR diets (Kobayashi et al., 1999). However, recovery appears to be delayed in grazing animals and occurs between 4 and 8 wk postcalving in cows of NZ origin (M. C. Lucy, personal communication). This corresponds well with the DIM to nadir BCS and BW in the study reported here. 
Although there was no effect of concentrates on rate of BW or BCS loss in the reported study, feeding concentrates reduced the time to nadir BCS and increased the nadir BCS and postnadir BCS gain. This may suggest a concentrate-induced accelerated recovery of hepatic GHR in grazing dairy cows. There is a sound physiological basis to believe this to be true. The abundance of hepatic and adipocyte GHR increases with increasing plasma insulin concentration (Rhoads et al., 2004). Concentrate supplementation alters the pathway of rumen fermentation from acetate-dominant toward propionate (Van Soest, 1994), and higher propionate production would be expected to increase insulin secretion (Sano et al., 1993) potentially resulting in earlier recovery of GHR. Further research is required to determine whether in fact concentrate supplementation alters the period of attenuated hepatic GHR concentration.

The tendency for a strain by level of concentrate feeding interaction in BCS at $270 \mathrm{DIM}(P=0.15)$ suggests that this effect of concentrates on GHR may be influenced by genetic strain of dairy cow. The hepatic production of IGF-I controls the production of GH through a negative feedback process. This is an important process because it is one of the factors that defines when body tissue mobilization should cease. The periparturient uncoupling of the GH-IGF-I axis (Rhoads et al., 2005) reduces the production of IGF-I, allowing a significant increase in GH above normal baseline concentrations (Kobayashi et al., 1999; Roche et al., 2005), facilitating a greater release of energy stores to support lactation (Bauman and Currie, 1980). A delay in the recovery of hepatic GHR-1A in NA cows relative to NZ cows has been reported (M. C. Lucy, personal communication), with no recovery in hepatic GHR-1A abundance in NA cows by 84 DIM (when measurements ceased). This slower replenishment of GHR in NA cows explains, at least in part, the lower BCS gain postnadir in NA cows.

\section{CONCLUSIONS}

The Wilmink exponential function explained $86 \%$ of the variation in milk yield, 62 to $69 \%$ of the variation in milk composition, and 80 and $70 \%$ of the variation in BW and BCS, respectively. North American cows were heavier and produced milk with lower fat and protein concentrations. They lost more BW postcalving than NZ cows and were at a lower BCS throughout lactation, even though BCS at calving was similar. Concentrate supplementation increased milk production and milk protein concentration throughout lactation, but reduced the concentration of fat in milk. Concentrates did not affect the rate of $\mathrm{BW}$ or BCS loss postcalving, but reduced the interval from calving to nadir BCS and BW, the amount of BCS lost, and the rate of BCS gain postna- dir. The effect of concentrates on BCS gain appeared to be affected by genetic strain.

\section{ACKNOWLEDGMENTS}

The authors acknowledge the technical assistance of P. Thorne, P. Aspin, and G. Ferguson and all the help afforded them by Dexcel Lye dairy farm staff. This work was funded by New Zealand Dairy Farmers, through the Dairy InSight research fund.

\section{REFERENCES}

Bargo, F., L. D. Muller, J. E. Delahoy, and T. W. Cassidy. 2002. Milk response to concentrate supplementation of high producing dairy cows grazing at two pasture allowances. J. Dairy Sci. 85:17771792.

Bargo, F., L. D. Muller, E. S. Kolver, and J. E. Delahoy. 2003. Invited Review: Production and digestion of supplemented dairy cows on pasture. J. Dairy Sci. 86:1-42.

Bauman, D. E., and B. Currie. 1980. Partitioning of nutrients during pregnancy and lactation: A review of mechanisms involving homeostasis and homeorhesis. J. Dairy Sci. 63:1514-1529.

Berry, D. P., F. Buckley, P. Dillon, R. D. Evans, M. Rath, and R. F. Veerkamp. 2003. Genotype X environment interaction for milk yield, body condition score, and body weight in a grass based system using random regression models. Livest. Prod. Sci. 83:191-203.

Buckley, F., K. O'Sullivan, J. F. Mee, R. D. Evans, and P. Dillon. 2003. Relationships among milk yield, body condition, cow weight, and reproduction in spring-calved Holstein-Friesians. J. Dairy Sci. 86:2308-2319.

Cobby, J. M., and Y. L. P. Le Du. 1978. On fitting curves to lactation data. Anim. Prod. 26:127-133.

Collard, B. L., P. J. Boettcher, J. C. M. Dekkers, D. Peticlerc, and L. R. Schaeffer. 2000. Relationships between energy balance and health traits of dairy cattle in early lactation. J. Dairy Sci. 83:2683-2690.

Dillon, P., D. P. Berry, R. D. Evans, F. Buckley, and B. Horan. 2006. Consequences of genetic selection for increased milk production in European seasonal pasture based systems of milk production. Livest. Sci. 99:141-158.

Dillon, P., S. Crosse, and B. O'Brien. 1997. Effect of concentrate supplementation of grazing dairy cows in early lactation on milk production and milk processing quality. Irish J. Agric. Food Res. $36: 145-159$

Dixon, R. M., and C. R. Stockdale. 1999. Associative effects between forages and grains: Consequences for feed utilization. Aust. J. Agric. Res. 50:757-773.

Etherton, T. D., and D. E. Bauman. 1998. Biology of somatotropin in growth and lactation of domestic animals. Physiol. Rev. 78:745761.

Fulkerson, W. J., J. Wilkins, R. C. Dobos, G. M. Hough, M. E. Goddard, and T. Davidson. 2001. Reproductive performance in HolsteinFriesian cows in relation to genetic merit and level of feeding when grazing pasture. J. Anim. Sci. 73:397-406.

Gordon, F. J., D. C. Patterson, T. Yan, M. G. Proter, C. S. Mayne, and E. F. Unsworth. 1995. The influence of genetic index for milk production on the response to complete diet feeding and the utilization of energy and protein. Anim. Sci. 61:199-210.

Harris, B. L., J. M. Clark, and R. G. Jackson. 1996. Across-breed evaluation of dairy cattle. Proc. N.Z. Soc. Anim. Prod. 56:12-15.

Harris, B. L., and E. S. Kolver. 2001. A review of Holsteinization on intensive pastoral dairy farming in New Zealand. J. Dairy Sci. 84(E. Suppl.):E56-E61.

Hart, I. C., J. A. Bines, S. V. Morant, and J. L. Ridley. 1978. Endocrine control of energy metabolism in the cow: Comparison of the levels of hormones (prolactin, growth hormone, insulin and thyroxine) and metabolites in the plasma of high- and low-yielding cattle at various stages of lactation. J. Endocrinol. 77:333-345. 
Horan, B., P. Dillon, D. P. Berry, P. O'Connor, and M. Rath. 2005a. The effect of strain of Holstein-Friesian, feeding system and parity on lactation curves characteristics of spring-calving dairy cows. Livest. Prod. Sci. 95:231-241.

Horan, B., P. Dillon, P. Faverdin, L. Delaby, F. Buckley, and M. Rath. 2005b. Strain of Holstein-Friesian by pasture-based feed system interaction for milk production, bodyweight and body condition score. J. Dairy Sci. 88:1231-1243.

Horan, B., P. Faverdin, L. Delaby, M. Rath, and P. Dillon. 2006. The effect of strain of Holstein-Friesian dairy cow and pasture-based system on grass intake and milk production. Anim. Sci. (accepted)

Jonsson, N. N., W. J. Fulkerson, P. M. Pepper, and M. R. McGowan. 1999. Effect of genetic merit and concentrate feeding on reproduction of grazing dairy cows in a subtropical environment. J. Dairy Sci. 82:2756-2765.

Journet, M., and C. Demarquilly. 1979. Grazing. Pages 295-321 in Feeding Strategy for the High Yielding Cow. W. H. Broster and H. Swan, ed. Granada Publishing Limited, Frogmore, St. Albans, UK.

Kellaway, R., and S. Porta. 1993. Feeding concentrates supplements for dairy cows. Dairy Research and Development Corporation, Melbourne, Australia.

Kennedy, J., P. Dillon, L. Delaby, P. Faverdin, G. Stakelum, and M. Rath. 2003. Effect of genetic merit and concentrate supplementation on grass intake and milk production with Holstein-Friesian dairy cows. J. Dairy Sci. 86:610-621.

Kennedy, J., P. Dillon, P. Faverdin, L. Delaby, F. Buckley, and M. Rath. 2002. The influence of cow genetic merit on response to concentrate supplementation in a grass based system. J. Anim. Sci. 75:433-446.

Kobayashi, Y., C. K. Boyd, C. J. Bracken, W. R. Lamberson, D. H. Keisler, and M. C. Lucy. 1999. Reduced growth hormone receptor (GHR) messenger ribonucleic acid in liver of periparturient cattle is caused by a specific down-regulation of GHR 1A that is associated with decreased insulin-like growth factor I. Endocrinology 140:3947-3954.

Kolver, E. S., J. R. Roche, M. J. de Veth, P. Thorne, and A. R. Napper. 2002. Total mixed ration versus pasture diets: Evidence of a genotype $\times$ diet interaction. Proc. N.Z. Soc. Anim. Prod. 62:246-251.

Lucy, M. C., H. Jiang, and Y. Kobayashi. 2001. Changes in the somatotropin axis associated with the initiation of lactation. J. Dairy Sci. 84(E. Suppl.):E113-E119.

Macdonald, K. A., and J. R. Roche. 2004. Condition scoring made easy. Condition scoring dairy herds. 1st ed. Dexcel Ltd., Hamilton, New Zealand.

Mao, I. L., K. Sloniewski, P. Madsen, and J. Jensen. 2004. Changes in body condition score and in its genetic variation during lactation. Livest. Prod. Sci. 89:55-65.

McGilloway, D. A., and C. S. Mayne. 1996. The importance of grass availability for the high genetic merit dairy cow. Page 135 in Recent Advances in Animal Nutrition. P. C. Garnsworthy, J. Wiseman, and W. Haresign, ed. Nottingham University Press, Nottingham, UK.

Miglior, F. 2005. Overview of different breeding objectives in various countries. J. Dairy Sci. 88:1255-1263.

Nelson, D. L., and M. M. Cox. 2005. Hormonal regulation and integration of mammalian metabolism. Pages 881-920 Lehninger Principles of Biochemistry. 4th rev ed. W. H. Freeman and Co., New York, NY.

Penno, J. W. 2002. The response by grazing dairy cows to supplementary feeds. PhD thesis. Massey University, Palmerston North, New Zealand.

Rhoads, R. P., J. W. Kim, B. J. Leury, L. H. Baumgard, N. Segoale, S. J. Frank, D. E. Bauman, and Y. R. Bosclair. 2004. Insulin increases the abundance of the growth hormone receptor in liver and adipose tissue of periparturient dairy cows. J. Nutr. 134:1020-1027.
Rhoads, R. P., M. L. Rhoads, and Y. R. Boisclair. 2005. Implications of a dysfunctional somatotropic axis during the transition period in dairy cattle. Pages 197-208 in Proc. Southwest Nutr. Conf. Univ. Arizona, Tucson.

Robaina, A. C., C. Grainger, P. Moate, J. Taylor, and J. Stewart. 1998. Responses to grain feeding by grazing dairy cows. Aust. J. Exp. Agric. 38:541-549.

Roche, J. R. 2006. Dry matter intake postcalving influences milk production response to precalving dry matter intake in grazing dairy cows. Livest. Sci. 99 (accepted)

Roche, J. R., P. G. Dillon, C. R. Stockdale, L. H. Baumgard, and M. J. VanBaale. 2004. Relationships among international body condition scoring systems. J. Dairy Sci. 87:3076-3079.

Roche, J. R., E. S. Kolver, and J. K. Kay. 2005. Influence of precalving feed allowance on periparturient metabolic and hormonal responses and milk production in grazing dairy cows. J. Dairy Sci. 88:677-689

Sano, H., N. Hattori, Y. Todome, J. Tsuruoka, H. Takahashi, and Y. Terashima. 1993. 1993. Plasma insulin and glucagon responses to intravenous infusion of propionate and their autonomic control in sheep. J. Anim. Sci. 71:3414-3422.

SAS Institute. 2005. User's Guide Version 9.1: Statistics. SAS Institute, Cary, NC

Spörndly, E. 1991. Supplementation of dairy cows offered freshly cut herbage ad libitum with starchy concentrates based on barley or fibrous concentrates based on unmolassed sugar beet pulp and wheat bran. Swedish J. Agric. Res. 21:131-139.

Stakelum, G. 1986. Herbage intake of grazing dairy cows. 3. Effect of herbage mass, herbage allowance and concentrate feeding on the herbage intake of dairy cows grazing on mid-summer pasture. Irish J. Agric. Res. 25:179-189.

Stockdale, C. R. 2001. Body condition at calving and the performance of dairy cows in early lactation under Australian conditions: A review. Aust. J. Exp. Agric. 41:823-829.

Tekerli, M., Z. Alinci, I. Dogan, and A. Akcan. 2000. Factors affecting the shape of lactation curves of Holstein cows from the Balikesir province of Turkey. J. Dairy Sci. 83:1381-1386.

Van Soest, P. J. 1994. Microbes in the gut. Pages 253-280 in Nutritional Ecology of the Ruminant. 2nd rev ed. Cornell University Press, Ithaca, NY.

Veerkamp, R. F., G. Simm, and J. D. Oldham. 1994. Effects of interaction between genotype and feeding system on milk production feed intake, efficiency and body tissue mobilization in dairy cows. Livest. Prod. Sci. 39:229-241.

Vernon, R. G. 1989. Endocrine control of metabolic adaptation during lactation. Proc. Nutr. Soc. 48:23-32.

Vernon, R. G. 1992. Control of lipogenesis and lipolysis. Pages 59-81 in The Control of Fat and Lean Deposition. K. M. Boorman, P. S. Buttely, and D. B. Lindsay, ed. Butterworth Heinemann, Oxford, UK

Wang, S., G. L. Roy, A. J. Lee, A. J. McAllister, T. R. Batra, C. Y. Lin, J. A. Vesely, J. M. Wauthy, and K. A. Winter. 1992. Genetic line $\times$ concentrate level interactions for milk production and feed efficiency in dairy cattle. Can. J. Anim. Sci. 72:227-236.

Wildman, E. E., G. M. Jones, P. E. Wagner, R. L. Boman, H. F. Troutt Jr., and T. N. Lesch. 1982. A dairy cow body condition scoring system and its relationship to selected production characteristics. J. Dairy Sci. 65:495-501.

Wilmink, J. B. M. 1987. Adjustment of lactation yield for age at calving in relation to level of production. Livest. Prod. Sci. 16:321-334.

Wood, P. D. P. 1976. Algebraic models of the lactation curves for milk, fat and protein production, with estimates of seasonal variation. Anim. Prod. 22:35-40.

Xing, G. Q., D. D. S. Mackenzie, S. N. McCutcheon, and B. W. Wickam. 1993. Pancreatic insulin responses to exogenous glucose in Friesian heifers of low or high genetic merit for milk-fat yield. Anim. Prod. 56:171-178. 